\title{
Die belang van Prof. F.J.van Zyl vir Hervormde Teologie
}

\begin{tabular}{|c|c|}
\hline $\begin{array}{l}\text { Author: } \\
\text { Jaco Beyers } \\
\text { 1,2 }\end{array}$ & \\
\hline $\begin{array}{l}\text { Affiliations: } \\
{ }^{1} \text { Department } \\
\text { Religion and } \\
\text { Faculty of The } \\
\text { University of } \\
\text { South Africa }\end{array}$ & $\begin{array}{l}\text { f Science of } \\
\text { Aissiology, } \\
\text { ology, } \\
\text { retoria, }\end{array}$ \\
\hline $\begin{array}{l}\text { 2Department } \\
\text { Religious Stud } \\
\text { Theology, Uni } \\
\text { Pretoria, Sout }\end{array}$ & $\begin{array}{l}\text { f Biblical and } \\
\text { ies, Faculty of } \\
\text { ersity of } \\
\text { Africa }\end{array}$ \\
\hline $\begin{array}{l}\text { Research Proj } \\
\text { Project Leade } \\
\text { Project Numb }\end{array}$ & $\begin{array}{l}\text { ct Registration: } \\
\text { r: J. Beyers } \\
\text { er: } 02440237\end{array}$ \\
\hline $\begin{array}{l}\text { Description: } \\
\text { This research } \\
\text { project, 'Relig } \\
\text { Culture', direc } \\
\text { Jaco Beyers, D } \\
\text { Science of Rel } \\
\text { Missiology, Fa } \\
\text { Theology, Uni } \\
\text { Pretoria. }\end{array}$ & $\begin{array}{l}\text { s part of the } \\
\text { on and } \\
\text { ted by Prof. Dr } \\
\text { epartment } \\
\text { gion and } \\
\text { culty of } \\
\text { jersity of }\end{array}$ \\
\hline $\begin{array}{l}\text { Correspondin } \\
\text { Jaco Beyers, } \\
\text { jaco.beyers@ }\end{array}$ & $\begin{array}{l}\text { g author: } \\
\text { p.ac.za }\end{array}$ \\
\hline $\begin{array}{l}\text { Dates: } \\
\text { Received: } 26 \\
\text { Accepted: } 15 \\
\text { Published: } 22\end{array}$ & $\begin{array}{l}\text { pr. } 2017 \\
\text { uly } 2017 \\
\text { Sept. } 2017\end{array}$ \\
\hline $\begin{array}{l}\text { How to cite th } \\
\text { Beyers, J., } 201 \\
\text { van Prof. F.J. v } \\
\text { Hervormde Te } \\
\text { Teologiese Stu } \\
\text { Theological St } \\
\text { a4604. https:/ } \\
\text { 10.4102/hts.v }\end{array}$ & $\begin{array}{l}\text { is article: } \\
\text { 7, 'Die belang } \\
\text { an Zyl vir } \\
\text { ologie', HTS } \\
\text { dies/ } \\
\text { udies 73(1), } \\
\text { /doi.org/ } \\
73 \text { i1.4604 }\end{array}$ \\
\hline $\begin{array}{l}\text { Copyright: } \\
\text { (c) 2017. The } \\
\text { Licensee: AOS } \\
\text { is licensed un } \\
\text { Creative Comr } \\
\text { Attribution Lic }\end{array}$ & $\begin{array}{l}\text { Iuthors. } \\
\text { IS. This work } \\
\text { der the } \\
\text { nons } \\
\text { ense. }\end{array}$ \\
\hline Read online: & \\
\hline 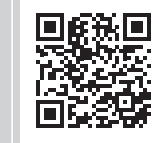 & $\begin{array}{l}\text { Scan this QR } \\
\text { code with your } \\
\text { smart phone or } \\
\text { mobile device } \\
\text { to read online. }\end{array}$ \\
\hline
\end{tabular}

In this article the contribution of professor Frans J. van Zyl (1913-2008) will be scrutinised as to determine the influence his thoughts had on the theology of the Netherdutch Reformed Church. As Van Zyl was seen as a follower of the theology of Karl Barth, his greatest influence centered around the ideas of Barth. Here, particular reference will be made to his view of the Bible and the Dialectical theology. The article also addresses the problem of the existence of so-called churchly theology and investigates the role Reformed theology played in the Netherdutch Reformed Church. The contribution Van Zyl made to Reformed theology is measured in terms of his contribution to (1) an understanding of God, (2) to a view on scripture and (3) his emphasis on the importance of mission work. Further, (4) his way of unselfishly serving in the church becomes a theological testimony to his character and example to the church. Lastly, (5) his condonation of white-only membership of the Netherdutch Reformed Church is not seen as a blemish to his name, but rather interpreted here as a continuation of the Reformed heritage in the sense that the nature of man is flawed by $\sin$.

\section{Inleiding}

Die kerk is groter as enige mens. Soms kan kennis en insigte van individue die kerk beïnvloed, hetsy tot die verryking van die kerk of tot die nadeel van die kerk. Dalk is dit juis God wat deur sy Gees gewone mense met gawes toebedeel om die kerk te lei en te stuur. So 'n profeet en leraar was professor Frans J. van Zyl vir die Hervormde Kerk.

Hierdie artikel wil allermins deelneem aan 'n vrome mensverheerliking of posthume vingerwysing, maar tog ondersoek hierdie artikel die bydrae wat die persoon Frans van Zyl tot die ontwikkeling van teologie binne die Hervormde kerk gemaak het. Alvorens so ondersoek gedoen word, is 'n begripsverduideliking nodig.

Hierdie artikel pretendeer dat daar wel so iets soos kerklike teologie bestaan en dat daar inderdaad iets genaamd Hervormde teologie is. Dit sou eers nodig wees om te verduidelik wat onder hierdie begrippe verstaan word.

Teologie kan met 'n verskeidenheid adjektiewe nader omskryf word. Teologie kan liberaal, bevrydend, dialekties, eties, westers, Reformatories, Bybels en vele meer wees. Dalk kan 'n paar van die etikette tegelyktydig op vorme van teologie beteken word. Etikette het die funksie om identiteit toe te ken. Identiteit bevorder eksklusiwiteit en stel strakke grense, soms tussen antisidente. Tog wil teologie teologie bly: spreke oor God soos wat God Homself openbaar (vgl Pannenberg 1973:266, 299). ${ }^{1}$ Juis hierin skuil die kruks: Solank as wat mense gedagtes oor God postuleer, sal verskeidenhede van teologieë bestaan. As God toegelaat word om oor Homself te praat, en die hoorder in eie woorde net napraat wat God sê, dan word teologie (Theos + Logos), logos-Theou [woorde van God]. Die logos is dan nie meer werkwoord gerig op 'n objek nie, maar die genetief dui aan dat dit woorde van God (oor Homself) is. Van hierdie tweegesprek tussen God en mens het Van Zyl die Hervormde Kerk kom bewus maak.

Van Zyl (1999) se evaluering van die aard van die Hervormde Kerk se teologie, lees soos volg:

Daarom moet teologie altyd nader bepaal word as kerklik, of Christelik, of Bybels-Reformatories. Ook ons teologie is ' $n$ ernstige poging om dit in die Bybels-Reformatoriese tradisie te beoefen, want 'n Christelike kerk kan nie 'n amptelike, offisiële teologie hê, sonder dat vryheid van ondersoek ernstig aan bande gelê word nie. (bl. 406)

1.Hierdie verwysing na Pannenberg het nie ten doel om Hervormde teologie te verduidelik nie, maar dien as omskrywing van die aard van teologie. 
Om hier reg te laat geskied aan die historiese figuur van professor Frans van Zyl, word eerstens 'n bondige biografiese oorsig van sy lewe gebied. Die inhoud hiervan stem grotendeels ooreen met die kronologie wat P.J. van der Merwe in 'n bydrae tot 'n huldigingsbundel in 1989 oor Van Zyl opgestel het. Vir biografiese gegewens wat nie deur Van der Merwe gemeld word nie, word die relevante bron gemeld. Sien ook die bydrae van Van der Merwe (1989:245-251) vir ' $n$ omvattende lys van al die publikasies van Van Zyl.

\section{Biografiese gegewens}

Francois Jacobus van Zyl is gebore op 06 Mei 1913 op 'n plaas in die Marico distrik in die noord-weste van Suid-Afrika. Hy matrikuleer aan die Hoërskool Zeerust (Oberholzer 2010:70). Gedurende die 1930's studeer hy teologie aan die Universiteit van Pretoria. Hy voltooi sy teologiese studies in 1938 as enigste finalejaarstudent van die Hervormde Kerk in daardie jaar. Hy word georden op 28 Mei 1939 in die kerkgebou van Cottesloe as medeleraar in die gemeente Johannesburg. Hier dien hy tot 1941 waarna hy 'n beroep aanvaar na gemeente Standerton. Van 1948 tot 1949 arbei hy in gemeente Lydenburg en aanvaar dan 'n beroep na gemeente Springs. In Springs gemeente arbei hy tot in 1957 waarna hy 'n beroep na gemeente Wonderboompoort in Pretoria aanvaar. Gedurende 1949-1957 werk hy aan sy doktorale studies. Hy promoveer 'met lof' in 1959 in Godsdiensfilosofie met 'n tesis getiteld 'Analogia entis: 'n Godsdiensfilosofiese ondersoek' met professor H.P. Wolmarans as studieleier (Oberholzer 2010:70). In 1960 word hy benoem as hoogleraar in die Departement Godsdiens- en Sendingwetenskap (Afd A) waarvan hy ook hoof word met die aftrede van professor H.P. Wolmarans in 1959. Na agttien jaar diens tree Van Zyl in 1978 af as hoogleraar maar dien steeds in gemeentes as predikant en selfs op kerklike strukture en rade tot en met 1982. Hy aanvaar 'n beroep na die gemeente Potchefstroom-Noord en arbei daar totdat hy die ouderdom (sewentig jaar) vir verpligte emeritaat in 1983 bereik waarna hy na Pretoria verhuis (Van der Merwe 1989:234). Hy sterf in 2008 en word te Pretoria begrawe.

Dit is opmerklik dat Van der Merwe (1989) weinig aandag gee aan die teologiese konteks asook internasionale formatiewe invloede op die teologie van Van Zyl. Hierdie artikel wil juis hierdie onbeskrewe geskiedenis uitwys en die teologiese konteks omskryf wat invloed op Van Zyl en gevolglik op die Hervormde teologie gehad het.

\section{Voorbereidende gesprek}

Hierdie artikel ondersoek die invloed wat Van Zyl op die teologie wat in die Hervormde Kerk beoefen word, gehad het. Dit veronderstel dat daar iets soos kerklike, asook Hervormde teologie, bestaan. So paar kantopmerkings is nodig alvorens na die invloed van Van Zyl gekyk word.

\section{Kerklike teologie}

Teologiese tradisie word bepaal deur dogmatiese, kerkregtelike en belydenismatige uitsprake (Dreyer 2003:1046). Die kerklike praktyke sou egter as manifestering van die teologie kon dien, alhoewel die praktyke dalk eerder die spiritualiteit reflekteer. ' $n$ Onderskeid tussen inhoud en vorm is dus nodig. Soortgelyke inhoud kan in 'n verskeidenheid vorme aangebied word. Binne die Hervormde tradisie het die kerklike etos nog in 'n groot mate die eenvormige verpakking van die teologiese inhoud bepaal. Eers nou in die onlangse verlede het vrymoedigheid ontstaan om die teologiese inhoud in verskillende vorme voor te hou (vergelyk in dié verband die loop-nagmaal).

Binne 'n Reformatoriese tradisie sou as riglyne vir 'n kerklike teologie dien die suiwer Woordverkondiging en sakramentsbediening asook die handhawing van kerklike dissipline, soos wat Nel die Nederlandse Geloofsbelydenis in hierdie verband opsom (2015:3). Dit veronderstel egter nog net die parameters waarbinne die teologiese tradisie ingeklee word. Die teologiese inhoud word fundeer op die teologiese arbied wat wetenskaplik verantwoord word. Vergelyk in hierdie verband Beyers (2016:8) wat aandui hoe teologie slegs wetenskap kan bly as dit 'n streng verbintenis met geloofsgemeenskappe behou. Kerklike teologie verwys na die eindpunt van teologie beoefening. Teologie as wetenskaplike refleksie mond uit in die vorming van geloof en geloofspraktyke in die kerk. Die wetenskaplike beoefening van teologie aan 'n universiteit is ten dienste van die geloofsgemeenskappe (kerke). Woltersdorff (1996:96) stel as voorwaarde vir verantwoordelike teologie beoefening dat teologie nie los van geloofsgemeenskappe beoefen kan word nie.

Teologie adviseer die kerk en die kerk konsulteer die teologie wat deur wetenskaplikes beoefen word. Op die manier is daar voortdurende interaksie tussen kerk en teologie as wetenskaplike aktiwiteit. Die Hervormde Kerk het nog altyd waarde daaraan geheg dat teologie vanuit die wetenskap, wat aan 'n universiteit in 'n fakulteit Teologie beoefen word, die kerklike teologie en bediening bepaal. Van Zyl as hoogleraar aan die Fakulteit Teologie, Universiteit van Pretoria, is ' $n$ tekenende voorbeeld van die klem binne die Hervormde Kerk op wetenskaplik verantwoordbare teologiese opleiding en beoefening aan 'n universiteit.

\section{Hervormde teologie}

Hervormde teologie dui die trajek van teologiese refleksie aan wat deur die Reformatoriese denke gelê is. Die Hervormde Kerk se teologie kan as Bybels-Reformatories getipeer word (Van Eck 2011:2). Die Reformatoriese beginsels van sola Scriptura, sola fide en sola gratia vorm die basis van die Hervormde teologie. Van Zyl (1999:411) oordeel juis dat die solus Christus die basis van die Reformasie asook die basis van die versoeningsleer van Barth is. Die vertrekpunt, die bron waaruit teologie geput word, kan niks anders as die Bybel wees nie. Oor Bybelse teologie, stel Van Zyl (1999):

Die Bybelse adjektief is belangrik omdat dit die enigste outentieke getuienis is van die menswording van God in Jesus Christus ... Die Reformatoriese adjektief is belangrik omdat dit getuig van die wyse waarop die Reformatore die Bybel verstaan 
het, naamlik as die skynbaar teenstrydige, onbegryplike werklikheid en waarheid dat die oppermagtige God 'n mens kan word sonder om God se soewereiniteit prys te gee, dat God tot ons mense kan praat deur die mensewoorde van hulle wat van God getuig in die woorde van die Bybel, deur die krag en verligting deur die Heilige Gees. (bl. 406)

Die prominensie van die Bybel is omdat 'dit die Boek is waardeur God Hom aan die mens openbaar', soos wat Geyser (1989:255) verwys na Van Zyl se eie woorde oor die saak. In hierdie opsig het Van Zyl ook die Hervormde Kerk met insig bedien oor hoe die Bybel hanteer moet word. Mense skryf die Bybel in hulle eie taal en idioom en tog is die Bybel meer as 'n menslike boek. Die Bybel is tegelyk die Woord van God (Van Zyl 1944c). Die Skrifbeskouing wat Van Zyl voorgehou het, sou vir baie lank die Hervormde Kerk leiding gee oor hoe om met die Bybel om te gaan. Vergelyk in hierdie verband die bespreking deur Geyser (1989) van Van Zyl se bydrae spesifiek tot die Skrifbeskouing van die Hervormde Kerk.

Gebaseer op die beskouing dat die Bybel die Woord van God is, vind die Hervormde Kerk aansluiting by die Reformatoriese tradisie. Reformatoriese teologie het as hart die regverdigingsleer (Van Wyk 2011:2). Hierdie regverdigingsleer word gebaseer op die Lutherse onderskeid tussen Wet en Evangelie (Van Wyk 2011:3). Op grond van die feit dat die mens in Christus deur God regverdig verklaar word, doen die mens nou goeie dade. Dit is nie deur die doen van goeie dade dat die mens regverdig word nie (Van Wyk 2011:4). Weens die feit dat die mens deur die genade van God regverdig verklaar is, is die mens nou vry om goed te doen. Uit dankbaarheid vir die versoening met God deur die verdienstelike dood van Christus, leef die mens gehoorsaam aan die wil van God.

Binne die Reformatoriese tradisie het die Hervormde teologie ook 'n bepaalde verstaan van die waarheid. Koekemoer (1995:877) is van mening dat Hervormde teologie die begrip waarheid as ontmoeting verstaan. Teologie is geen esoteriese bedryf nie, maar is denkarbeid ten dienste van die kerklike verkondiging (Koekemoer 1995:878). Van Zyl het 'n groot gewag gemaak van die ontmoetingsgebeure met God wanneer die mens met die Woord van God besig is (Geyser 1989:259). Van Zyl se verstaan van waarheid as ontmoetingsgebeure kan teruggevoer word na sy verstaan van Brunner. Vergelyk in dié verband Geyser (1989:260) se evaluering van 'n artikel wat Van Zyl (1944a, b, c, d, e) oor die Bybel gemaak het.

Die geskil in kerklike kringe is die vraag 'wat lê aan die wortel van Hervormde teologie?' Vir Buitendag (1992:1) is die groeibodem vir Hervormde teologie die Etiese teologie wat gedurende die negentiende eeu in Nederland bo-toon gevoer het. Met Etiese teologie word verwys na 'n beweging in Nederland tydens ongeveer die periode 1850-1920 wat as die Etiese (of etici) bekendgestaan het. Die woord is afkomstig uit die Grieks en verwys na 'n poging van lede van hierdie beweging om so na as moontlik aan die wese van die waarheid te kom (Loader 1996:578). Hierdie teologiese rigting het voorgehou dat die wese van die waarheid skuil in die ontmoeting met God en is nie te vinde in leerstellings nie. Loader (1989:432) stel dit onomwonde dat die Etiese teologie groot invloed op die Hervormde teologie, met die totstandkoming van 'n eie teologiese opleiding in Pretoria, uitgeoefen het. Al was daar later jare teenkanting, is die teologie van die Hervormde Kerk deur die etiese teoloë (soos onder andere H.P. Wolmarans, voorganger en promotor van F.J. van Zyl) bepaal.

Die teenparty word egter verteenwoordig deur stemme soos vroeër by Pont (1992) en later meer getemper by Dreyer (2015:303) wat aandui dat dit nie so eenvoudig is om die Etiese teologie as deurslaggewend vir die Hervormde teologie te beskou nie. As alternatief vir die Etiese teologie sou die standpunt van die Ortodoksie of Konfessionaliste wees wat voorhou dat God te vinde is in die sisteem van waarhede; in die leer. Daaruit word die verstaan van God dan georden (vgl Loader 1996:579). Kortom wil die etiese standpunt iets oor God sê in die ontmoeting met God en nie iets oor God terugskouend sê na die ontmoeting met God nie (Loader 1996:580). Alhoewel daar teenstemme binne die Hervormde Kerk was (vergelyk Loader wat Pont in die verband identifiseer (1996:580)), en sekerlik nog is, is dit duidelik dat die Etiese teologie via die Dialektiese teologie groot invloed op die Hervormde teologie uitgeoefen het. Die dialektiek maak ruimte om ten spyte van die voorlopige spreke oor God steeds in geloof vas te hou aan die belydenis. Die Konfessionalisme beklemtoon die ewig-vasstaande belydenis as onbetwisbare spreke oor God.

Dit hou implikasie in vir die hantering van die Skrif in die geloofsoeke na antwoorde vir lewenskwessies. Navolgers van die Dialektiese teologie het die Hervormde Kerk geleer om versigtig uitsprake vanuit die Skrif te mak. Die Skrif word nie hanteer as 'n Boek met ewig-geldende waarhede nie, maar as mense se spreke en denke vanuit 'n ontmoeting met God en hoe dit hulle lewe affekteer. Hierdie menslike denke en spreke moet telkens oorweeg word in elke nuwe lewensomstandigheid.

Hervormde teologie het ook missionale tendense. Sommige sou hierdie as 'n laat ontwikkeling in die Hervormde Kerk aandui en tog is die verstaan van sending as essensie van kerk wees lank reeds deel van die teologiese mondering van die Hervormde Kerk. Van Wyk (1989) dui aan watter rol Van Zyl as sendingteoloog binne die Hervormde Kerk gespeel het om die belang van sending in die Hervormde Kerk te vestig. Alhoewel Van Zyl dalk nooit die term missionaal gebruik het nie, was sy nadenke oor sending waardevol om die kerk voor te berei en te begelei om sending as essensie van kerk wees te verstaan (vgl Van Wyk 1989:268). Van Zyl was deel van die stemme wat daartoe bygedra het dat die Algemene Kerkvergadering van die Hervormde Kerk in 1945 die besluit geneem het om nie langer die sendingverantwoordelikheid te ontduik nie (Notule Algemene Kerkvergadering Beskrywingspunt 17 1945:59, 62). By die vergadering word ds F.J. van Zyl tot die Kommissie vir Evangelisasie verkies. 
Die belang van sending het tot vandag toe invloed op die Hervormde Kerk se verstaan uitgeoefen. Die belang van sending is sigbaar in die hernude verbintenis tot missionale kerk wees (Notule van die Algemene Kerkvergadering Beskrywingspunt 21 2016:140).

Vir Van Zyl is sending slegs gefundeer in die Skrif, en wel die hele Skrif (Van Wyk 1989:268). Volgens van Zyl weerklink binne die Ou sowel as die Nuwe Testament die getuienis en opdrag om die bekendmaking van die heerskappy van Christus oor al die nasies, aan te kondig (Van Wyk 1989:267).

Die teologiese konteks waarbinne Van Zyl geleef en gewerk het, het sy sendingteologie en gevolglik die teologie van die Hervormde Kerk beïnvloed. Van Zyl het binne die konteks van sy tyd klem geplaas op die kultuur-eie sending. Elke kultuur moet in hulle eie taal die evangelie hoor en kerk wees in eie omgewing (vergelyk Van der Merwe 1989:242). Om hierdie roeping uit te leef het die Hervormde Kerk doelbewus gekies vir die gestalte van die volkskerk (Van Wyk 1989:276). Vir Van Zyl was die klem egter nooit op die volk as 'eienaar' van die kerk nie, maar eerder die volk as objek van die prediking en pastorale sorg van die kerk. Sommige binne die Hervormde Kerk het die teologiese trajek wat deur die apartheidsdenke gevestig is, gevolg om die Hervormde Kerk eksklusief ' $n$ blanke kerk te maak. Vir Van Zyl was die hoofsaak egter dat die evangelie aan al die nasies bekendgemaak word (Van Wyk 1989:267).

Tog is teen die grein van sy gedagtes, Van Zyl se bydrae tot die opstel van die Herderlike Skrywe van 1973 wat die bestaansreg van Artikel III, wat lidmaatskap van die Hervormde Kerk tot blankes bepaal het, sigbaar (Van der Merwe 1989:239). Ten spyte van sy oortuiging dat die evangelie aan alle volke gebring moet word, het Van Zyl die eksklusiwiteit van die Hervormde Kerk verdedig. Was sy verdediging van Artikel III gebaseer op 'n verstaan van 'n skeppingsorde waar volke hierargies bestaan, of was dit die blinde napraat van 'n Afrikaner ideologie? Hierdie vraag is moeilik te beantwoord aangesien Van Zyl telkemale die verkondiging van die evangelie aan alle nasies sou bepleit en nie net die beperking van die evangelie tot die Afrikanervolk nie (Van Wyk 1989:276). Vergelyk in hierdie verband Van Zyl se bespreking in die Almanak van 1942 van die kerk se verantwoordelikheid teenoor die volk: 'Die taak van ons kerk is 'n sendingtaak'.

Hervormde teologie kan dus soos volg tipeer word: BybelsReformatories, wetenskaplik, eties-dialekties en missionaal. Op al drie hierdie terreine is Van Zyl se invloed op die Hervormde Kerk sigbaar.

\section{Teologie beoefening Volstrekte Barthiaan}

Van der Merwe en Van Wyk (1992:383) maak die stelling dat Van Zyl waarskynlik die eerste Hervormde teoloog was wat intensief kennis geneem het van die teologie van Karl Barth. Van Zyl (1992:367) self dui egter aan dat die Hervormde teoloog wat die Hervormde Kerk aan die Dialektiese teologie van Karl Barth blootgestel het, sy voorganger, professor H.P. Wolmarans was. Die indruk word geskep dat Wolmarans die eerste treë nader aan die Dialektiese teologie gegee het met Van Zyl wat hom opvolg en die Hervormde Kerk begelei tot die konsolidasie en begrip van die implikasies van die Dialektiese teologie. Die blootstelling binne die Hervormde Kerk aan Dialektiese teologie het egter op 'n veel wyer front plaasgevind. Dosente aan die Fakulteit Teologie (Afd A) by die Universiteit van Pretoria, soos professor B.J. Engelbrecht, het reeds gebruik gemaak van die dogmatiek handboeke van Van Niftrik en Heitjema wat volgelinge van die teologie van Barth was. Wolmarans, en later Van Zyl en B.J. Engelbrecht, het predikante in die Hervormde Kerk opgelei binne hulle verstaan van die tradisie van die Dialektiese teologie.

Daar is vroeër in die biografiese afdeling van hierdie artikel reeds verwys na die merkwaardige dat daar tydens die periode van isolasie in Suid-Afrika soveel kontak met teologiese ontwikkeling in Europa was dat Van Zyl (en selfs Wolmarans) nie net kennis geneem het van die Dialektiese teologie nie, maar selfs op hoogte was van die inhoud daarvan. Dit was grootliks te danke aan die beskikbaarheid van die Nederlands theologisch tijdschrift in Suid-Afrika waarin die nuutste publikasies in teologie in Europa aangekondig is. Dit het geleentheid aan teoloë gebied om kennis van die nuutste boeke in teologie te neem. Individue soos B.J. Engelbrecht, P.S. Dreyer en S.P. Engelbrecht het studies in Nederland onderneem wat weer 'n kanaal geskep het om inligting oor die nuutste teologiese tendense in Europa na Suid-Afrika te bring.

Wat die bewus wees van Dialektiese teologie so merkwaardig maak, is juis die feit dat Van Zyl sy doktorale studies afhandel binne 'n konteks van isolasie van Suid-Afrika. Sedert die 1940-1960's betree Suid-Afrika toenemend 'n era van pariah status op grond van die apartheidsbeleid van die regering. Ekonomies, polities asook akademies het Suid-Afrika verval in 'n era van isolasie. Min kontak met oorsese akademici was moontlik. Dit bly dus merkwaardig dat Van Zyl en ander teoloë van Suid-Afrika gedurende hierdie periode op hoogte kon kom en bly van teologiese ontwikkelinge in Europa. Dit is juis die tydperk waarin die Dialektiese teologie beslag in Europa onder Karl Barth vind.

Ten spyte van sy kennis van Barth, was Van Zyl ook beïnvloed deur die denke van Emil Brunner en Hendrik Kraemer (Van der Merwe \& Van Wyk 1992:384). Kraemer moet ook as Barthiaanse teoloog gereken word. Wolmarans was geneig om meer van die teologie van Brunner te maak en het op so 'n wyse Van Zyl ook aan Brunner blootgestel. Van Zyl het meer klem op die teologie van Barth geplaas. Van Zyl het Godsdiensfilosofies gesproke nader aan Brunner as aan Barth gestaan (Van der Merwe et al. 1992:384).

Van Zyl is in sy teologiese denke 'n geswore Barthiaan. Tog is Van Zyl krities oor Barth (1999:419) wanneer hy oordeel dat die invloed van die Dialektiese teologie in die Hervormde Kerk maar gering is. Van der Merwe (1989:235) dui aan hoe Van Zyl 
in opdrag van die kerk die skrifbeskouing van Barth bestudeer en die kerk daaroor onderrig het. Dit doen Van Zyl ondermeer in die volgende publikasies: Die Hervormer (verskeie uitgawes 1944-1945), in die Hervormde Teologiese Studies (1944:1/3) en 'n publikasie getiteld Die Boek van alle boeke: Ons Bybel in 1948. Barthiaanse teologie begin met die uitwys van die menslike onvermoë om oor God te praat. Op die vraag wie God is, antwoord Barth dat Hy die Onbeskryflike is wat slegs kenbaar is deur sy openbaring in die Woord deur Jesus (Bromiley 1979:14). Wat hier van belang is, is die prominensie van die Woord en die trinititeit. Die skrifbeskouing is dus belangrik. Die mens ken God slegs in Christus soos geopenbaar in die Skrif. Op die openbaring reageer die mens met geloof. God is egter nie 'n objek nie (Bultmann 1984:53). God is deel van die metafisiese werklikheid wat die mens probeer verstaan. Die mens se verstaan van God loop uit op geloof. Geloof is volgens Barth, 'n subjektiewe menslike reaksie, 'n reaksie uit gehoorsaamheid (in Pannenberg 1973:274).

Wat het die mens dan met God te maak? Om oor God te praat moet 'n mens oor die mens praat, en om oor die mens te praat, moet 'n mens oor God praat. Die mens bly skepsel van God (Bromiley 1979:124). Om die mens te verstaan, moet 'n mens eers die mens Jesus verstaan. In Jesus ontdek die mens die eie identiteit voor God. Barth se vertrekpunt is die kennis van God in Jesus Christus. Die belang van Christus hang af van die sondeleer. Dit is egter 'n antropologiese vertrekpunt. In die mens se soeke en ontmoeting met God, ontdek die mens die self as ongehoorsaam aan die heilige God, die mens in verset teen God, die 'mens-van-sonde' (Van Zyl 1993:5).

Die Dialektiese teologie het eie aan die Hervormde Kerk geword juis omdat dit as die voortsetting van die Reformatoriese tradisie beleef is. Van Zyl was instrumenteel in die konsolidasie van hierdie teologie in die Hervormde Kerk. Tog het die Barthiaanse teologie leemtes wat vandag ook in die Hervormde teologie te bespeur is.

Barth se Christo-sentrisme laat die teologie met 'n leemte. Deur net te fokus op die implikasie van die Christus-gebeure vir die sondaar mens, mis die teologie uit op ander teologiese klemtone, byvoorbeeld die teologiese belang van ekologie en sosiale opheffing. Eers in die onlangse verlede het die Hervormde Kerk kennis geneem van die ekologiese verantwoordelikheid en klem op sosiale opheffing in die Suid-Afrikaanse konteks. Die eerste teoloog in die Hervormde Kerk om die kerk bewus te maak van die eko-teologie is professor J.H. Buitendag (vgl Buitendag 1985).

Hierdie artikel het nie ten doel om die Dialektiese teologie te evalueer in die effektiwiteit of kwaliteit wat dit het nie. Hier is die doel om aan te dui hoe Van Zyl die Dialektiese teologie binne die Hervormde teologie laat posvat het.

\section{Godsdienswetenskap en teologie}

Van Zyl as promovendus in Godsdiensfilosofie, lewer 'n bydrae tot die teologie beoefening binne die Hervormde Kerk deur die teologiese ensiklopedie te orden.
Godsdienswetenskap en Godsdiensfilosofie is twee aparte dissiplines vir Van Zyl (Van der Merwe 1989:236). Godsdiensfilosofie wat as vertrekpunt die natuurlike teologie het, het nie bestaansreg binne teologie nie. So ook het fundamentele Godsdienswetenskap, wat Van Zyl 'fenomenologie van die godsdiens' (1973:150) noem, wel bestaansreg, maar kwalifiseer nie as teologie nie. Dit konsentreer te veel op die kulturele verskynsel van godsdiens en hoort tuis binne die geesteswetenskappe. Selfs filosofiese godsdiensfilosofie het bestaansreg maar kwalifiseer nog nie om teologie te wees nie (Van Zyl 1973:150). Van Zyl voel homself tuis in die godsdiensfilosofie soos Emil Brunner dit verstaan (Van Zyl 1973:153). Godsdiensfilosofie behoort die ruimte te wees waarbinne teologie besin oor die verskynsel godsdiens (theologia religionis) en tegelykertyd filosofie as gespreksgenoot het (Van der Merwe 1989:237).

Dreyer (2015:51) omskryf Van Zyl se verstaan van Godsdienswetenskap wanneer hy stel dat die eerste doelstelling van Godsdienswetenskap is die daarstel van 'n theologia religionis wat 'n verstaan van wat godsdiens is, vergemaklik; 'nie ... in die fenomenologiese sin nie, maar in teologiese sin, dit wil sê in die lig van die openbaring'. Die theologia religionis is dan die hoogtepunt van die Godsdienswetenskap ten dienste van teologie (Van der Merwe 1989:237).

Van Zyl is egter ook Barthiaans in sy nadenke oor die aard van godsdiens. Godsdiens is 'n kulturele en menslike verskynsel. In dié opsig stem Van Zyl saam met Barth se stelling dat teologie nie op godsdiens gefundeer kan word nie, aangesien godsdiens in die mens gesetel is (Van Zyl 1973:151). Van Zyl bevestig dat Brunner egter godsdiensfilosofie vir die teologie gered het deur godsdiensfilosofie in die teologie te fundeer (Van Zyl 1973:151). Van Zyl eggo wat Calvyn reeds in die eerste hoofstukke van sy dogmatiek aangedui het: godsdiens is menslike pogings om uit te reik na die goddelike. Tipies Barthiaans, behou Van Zyl ook 'n onderskeid tussen geloof en godsdiens (Van Zyl 1973:151, 154). Geloof is die gehoorsame menslike reaksie op die openbaring van God in Christus. Die wyse waarop hierdie geloofsverhouding tussen God en mens gestalte en uitdrukking vind, is godsdiens.

Die implikasie hiervan vir die kerk is dat die kerk opnuut moet ontdek dat die wese van die kerk nie daarin skuil om net 'n godsdienstige gemeenskap te wees nie, maar dat die kerk se wese in der waarheid daarin skuil dat die kerk 'n geloofsgemeenskap is (Van der Merwe 1989:241). Onder nuwe en veranderende omstandighede moet die kerk nuwe vorme van bestaan bedink hoe die kerk geloofsgemeenskap, getrou en gehoorsaam aan die evangelie, kan wees.

\section{Teologiese belang vir die Hervormde Kerk}

Die invloed wat Van Zyl op die teologiese denke in die Hervormde Kerk uitgeoefen het, is onbetwisbaar. Van Wyk (1989) verwoord dit soos volg: 
Deur sy artikels in kerklike publikasies en voordragte tydens vergaderings, het prof Van Zyl ook op die wyere teologiese denke en ontwikkeling in die Nederduitsch Hervormde Kerk sterk invloed uitgeoefen. Sy voordragte, in die klas en voor vergaderings, het daarvan getuig dat die waarhede van die evangelie vir hom deurleefde werklikheid is wat aangryp en ontroer. (bl. 277)

Die bydrae wat Van Zyl tot die teologie beoefening binne die Hervormde Kerk gemaak het, kan op verskeie terreine aangedui word.

\section{Godsbegrip}

Vanuit die Dialektiese teologie het Van Zyl beklemtoon dat spreke oor God is nederige en geweegde woorde. Die onbeskryflike God laat die mens net toe om oor Hom te praat in terme van dit wat Hy oor Homself aan die mens openbaar. Vergelyk in dié verband Van Zyl (1944e:134): 'Dis alleen genade dat ons deur die geloof God in die Skrif kan ken'. God openbaar Hom deur sy Woord in Jesus Christus. God se verhouding met die mens kom tot stand deur God se werking in Jesus aan die kruis. Ontmoeting met God roep die mens op tot geloof. Uitdrukking van geloof vind plaas in menslik, kultuur-gedrewe vorme en staan bekend as godsdiens.

Die mens het opdrag om oor God se genade in Christus te getuig. Hierdie verkondiging vind slegs plaas deur die verkondiging van die Woord. Vir Van Zyl is sending niks anders as verkondiging nie (Van Zyl 1972:178). Binne die Hervormde Kerk staan Woordverkondiging sentraal in die kerklike bedieningsstrukture. Kennis van God kom slegs deur Woordverkondiging (Van Zyl 1972:178).

\section{Skrifbeskouing}

Van Zyl het die Hervormde Kerk kom leer van 'n nugtere Skrifbeskouing. Die Bybel is mense woorde oor God (Geyser 1989:255); menslike getuienis oor die Openbaring (Geyser 1989:257). Die waarheid van die Skrif word nie begrond op die onfeilbaarheid van die Skrif nie. Ons ontdek die waarheid nie in 'n onfeilbare Skrif nie, maar in ontmoeting met Jesus (Geyser 1989:260). Die stelling dat die Bybel God se Woord in mensetaal is, is die basiese Skrifbeskouing van die Hervormde Kerk. Hierdie Hervormde teologiese formulering van Skrifbeskouing kan terug gevoer word na Barth via Van Zyl (Dreyer 2015:48). Barth stel dit in KD1/II: 'In the Bible we meet with human words in human speech, and in these words, and therefore by means of them, we hear the lordship of the triune God ...' (Barth 1970:463).

Die Etiese teologie se bydrae tot die Barthiaanse Skrifbeskouing is duidelik. Die etiese opvatting is dat die openbaring van God juis nie in begrippe vasgevang is nie, maar te vinde is in Christus (Loader 1996:583).

Die nugtere Skrifbeskouing waartoe Van Zyl bygedra het, word soos volg geformuleer:
In 'n tyd toe 'n pre-kritiese fundamentalistiese Skrifgebruik algemeen gangbaar was in die Afrikaanse kerke en teologie (veertigerjare), stel Van Zyl 'n Skrifbeskouing wat die moderne Bybelwetenskap in 'n groot mate geantisipeer en verdiskonteer het. (Van der Merwe 1989:242)

\section{Sendingbewussyn}

Deur sy publikasies het Van Zyl 'n reuse bydrae gelewer om 'n nuwe gesindheid binne die Hervormde Kerk teenoor sending te kweek (Van der Merwe 1989:242). Van Zyl se teologiese arbeid op die gebied van sendingwetenskap word deur Van Wyk (1989:278) beoordeel dat Van Zyl moes hom sendingteologies afgrens teen die rewolusionêre ontwikkeling in die ekumeniese sendingteologie na die Tweede Wêreldoorlog. Die resultaat van die strydvoering was dat hy nie veel impak met sy sendingteologie kon maak nie. Tog, op kerklike terrein kon Van Zyl die Hervormde Kerk voortdurend herinner aan die realiteit van kerk wees met 'n sendingopdrag. Vir Van Zyl was dit duidelik dat die Hervormde Kerk se sending aktiwiteite '... lê dus meer in die bydrae wat hy lewer om die bestaande kerk op te bou en te laat groei na Christus toe ...' (Van Zyl 1972:181). Die doel van sending is om die wêreldheerskappy van Christus te proklameer (Van Zyl 1972:7).

Sy voortgesette pogings om sending op die agenda van die Hervormde Kerk te hou, het daartoe gelei dat voortdurende debat oor sending in die Hervormde Kerk gevoer is.

\section{Etiek van werk}

Van Zyl het nie net in sy talle voordragte en artikels 'n bydrae tot die Hervormde Kerk se teologie gemaak nie. Sy lewe en arbeid binne die kerk was 'n toonbeeld van harde werk. Van sy studente dae af is dit duidelik dat sy lewe gekenmerk is deur 'n eerbare werksetiek. Ten spyte van struikelblokke om studiemateriaal te bekom en moeite om op hoogte van teologiese ontwikkelinge te bly, het hy steeds volgehou met harde akademiese werk. Die lang rits van publikasies (vergelyk die volledige lys van publikasies van Van Zyl in Van der Merwe 1989:245-251) is 'n aanduiding van sy vrugbare akademiese loopbaan. Die onbaatsugtige wyse waarop hy in diens van die kerk gedien het, as predikant, hoogleraar en lid van verskeie kommissies en rade, dien tot voorbeeld vir ampsdraers in die Hervormde Kerk. Van der Merwe beklemtoon juis die feit dat Van Zyl as 'kerkman' (Van der Merwe 1989:233) gereken moet word. Sy akademiese arbeid het hom nooit van die kerklike praktyk vervreem nie. Selfs na sy aftrede as hoogleraar het hy kans gesien om in 'n gemeente ten dienste van die kerk te werk. Sy lewe as toegewyde kerkman het die werksetiek van predikante van die kerk beïnvloed.

\section{Menslike feilbaarheid}

Die kerk is groter as enige mens. Van Zyl, ten spyte van al sy positiewe karaktereienskappe en onbetwisbare bydrae tot Hervormde teologie, was 'n mens uitgelewer aan die indrukke en invloede van sy tyd. Sy deelname aan die opstel 
van die Herderlike Skrywe 1973, staan onuitwisbaar in terme van sy ondersteuning van 'n saak soos blanke lidmaatskap van die Hervormde Kerk soos verwoord in Artikel III van die Kerkorde. Ten spyte van herhaalde uitsprake dat die hele evangelie deur die hele kerk aan alle nasies gebring moet word, staan Van Zyl steeds uit as Afrikaner nasionalis wat die grense van die volk van God soms laat oorvleuel met die grense van die Afrikaner volk:

Wanneer die eerste en hoogste verlange van elke lid van die volk is dat die hele volk van God mag wees, dan eers word die ware, Christelike, geheiligde nasionalisme gebore. (Van Zyl 1942)

Selfs sy nalatenskap aan die teologiese erfenis van die Hervormde Kerk bevestig die dialektiese aard van sy teologiese denke. Dit kan in die kerk nooit oor mense gaan nie. Mense is feilbaar, selfs in hulle beste pogings om God en die koninkryk te dien.

\section{Konklusie}

Frans van Zyl se bydrae tot die teologie in die Hervormde Kerk is van onskatbare waarde. Sy refleksie op die dialektiese teologie het die Hervormde Kerk in 'n bepaalde teologiese rigting gestuur en sy Skrifbeskouing het as instrument gedien hoe om die roetekaart te lees. Deur die gesprek oor sending op die agenda van die Hervormde Kerk te hou, is die kerk voortdurend herinner aan die evangeliese opdrag om die evangelie aan almal te bring.

\section{Erkenning Mededingende belange}

Die outeur verklaar dat hy geen finansiële of persoonlike verbintenis het met enige party wat hom nadelig kon beïnloed het in die skryf van hierdie artikel nie.

\section{Literatuurverwysings}

Barth, K., 1970, Church dogmatics Vol 1/II, G.W. Bromiley \& T.F. Torrance, T.F. (reds.), T\&T Clark, Edinburgh.

Beyers, J., 2016, 'Theology and higher education: The place of a Faculty of Theology at a South African university', HTS Teologiese Studies/ Theological Studies 72(4), a3450. https://doi.org/10.4102/hts.v72i4.3450

Bromiley, G.W., 1979, An introduction to the theology of Karl Barth, William B. Eerdmans Publishing Company, Grand Rapids, MI.

Buitendag, J., 1985, 'Skepping en Ekologie. 'n Sistematiese ondersoek na die teologiese verstaan van die werklikheid', Ongepubliseerde DD proefskrif, Universitiet van Pretoria.

Buitendag, J., 1992, Die etos van die Nederduitsch Hervormde Kerk, ongepubliseerde memorandum in Handelinge van die TKK, Argief van die Nederduitsch Hervormde Kerk, Pretoria.

Bultmann, R., 1984, Theology as science (1941) in R. Bultmann (ed.), New Testament and Mythology: And other basic writings, pp. 44-76, Selected, edited and trans S.M. Ogden, SCM Press, London.

Dreyer, T.F.J., 2003, 'Statistieke vertel 'n storie: ' $n$ Visie vir die Hervormde Kerk op pad na 2010', HTS Teologiese Studies/Theological Studies 59(4), 1045-1062. https:// doi.org/10.4102/hts.v59i4.685
Dreyer, W.A., jnr, 2015, 'Die interpretasie van die Dialektiese teologie deur Hervormde teoloë', ongepubliseerde MDiv skripsie, Universiteit vn Pretoria.

Geyser, P.A., 1989, 'Prof dr FJ van Zyl se Skrifbeskouing', HTS Theological Studies 45(2), 253-262. https://doi.org/10.4102/hts.v45i2.2254

Herderlike Skrywe, 1973, Argief van die Nederduitsch Hervormde Kerk, Kital:Pretoria.

Koekemoer, J.H., 1995, 'Die etos van die Nederduitsch Hervormde Kerk', HTS Teologiese Studies/Theological Studies 51(3), 876-880. https://doi.org/10.4102/ hts.v51i3.1447

Loader, J.A., 1989, 'Ontstaan en eerste periode van die Hervormde teologiese Opleiding aan die Universiteit van Pretoria', HTS Teologiese Studies/Theological Opleiding aan die Universiteit van Pretoria', HTS Teologiese Studie
Studies 437. https://doi.org/10.4102/hts.v45i2.2284

Loader, J.A., 1996, "n Hervormde tradisie as heelmiddel', HTS Teologiese Studies/ Theological Studies 52(4), 566-589. https://doi.org/10.4102/hts.v52i4.1543

Nederduitsch Hervormde Kerk van Afrika, 1945, Notule, Algemene Kerkvergadering, Argief van die Nederduitsch Hervormde Kerk, Pretoria.

$\mathrm{Nel}$, J., 2015, 'Die etos van die Hervormde Kerk in die derde Millenium', HTS Teologiese Studies/Theological Studies 71(3), Art \#3064, 1-7. https://doi.org/10.4102/hts. v71i3.3064

Nederduitsch Hervormde Kerk van Afrika, 2016, Notule, Algemene Kerkvergadering, Argief van die Nederduitsch Hervormde Kerk, Pretoria.

Oberholzer, J.P., 2010, 'Politieke spanning en ekumeniese druk 1954-1960', in 'Honderd Jaar Kerk en Teologiese Opleiding: ' $n$ Kroniek van die Hervormde Kerk', 'Honderd Jaar Kerk en Teologiese Opleiding: 'n Kroniek van die Hervormde Kerk',
HTS Teologiese Studies/Theological Studies 66(3 Suppl 9), Art. \#920, 1-10. https:// HTS Teologiese Studies/Theological
doi.org/10.4102/hts.v66i3.920

Pannenberg, W., 1973, Wissenschaftstheorie und Theologie, Suhrkamp Verlag, Frankfurt am Main.

Pont, A.D., 1992, 'Kerkgeskiedenis in ons teologiese opleiding: 1917-1956', HTS Teologiese Studies/Theological Studies 48(1 en 2), 253-272.

Van der Merwe, P.J., 1989, 'Prof dr FJ van Zyl as mens, kerkman en godsdiensfilosoof', HTS Teologiese Studies/Theological Studies 45(2), 231-252. https://doi. org/10.4102/hts.v45i2.2253

Van der Merwe, P.J. \& Van Wyk, D.J.C., 1992, 'Francois Jacobus Van Zyl, hooglereaar 1960-1978', HTS Teologiese Studies/Theological Studies 48(1\&2), 381-405.

Van Eck, E., 2011, 'Redaksioneel tot die T.F.J. Dreyer Huldigingsbundel', HTS Teologiese Studies/Theological Studies 67(3), Art. \#1124, 1-6. https://doi.org/10.4102/hts. v67i3.1124

Van Wyk, D.J.C., 1989, 'Prof dr FJ van Zyl as sendingteoloog', HTS Teologeise Studies/ Theological Studies 45(2), 263-279.

Van Wyk, I.W.C., 2011, 'Wat is reformatoriese teologie?: Nadenke na aanleiding van 'n kerklike beswaarskrif', HTS Teologiese Studies/Theological Studies 67(3), Art. \#1156, 1-11. https://doi.org/10.4102/hts.v67i3.1156

Van Zyl, F.J., 1942, 'Ons kerk en ons volk', Almanak 36, 58-62.

Van Zyl, F.J., 1944a, 'Die Boek van alle boeke: Ons Bybel: Inleiding', Die Hervormer 35(2), 6.

Van Zyl, F.J., 1944b, 'Die Boek van alle boeke: Ons Bybel: Die inhoud van die Bybel', Die Hervormer 35(3), 13

Van Zyl, F.J., 1944c, 'Die Boek van alle boeke: Ons Bybel: Mensewoord en Gods Woord', Die Hervormer 35(4), 7-8.

Van Zyl, F.J., 1944d, 'Die Boek van alle boeke: Ons Bybel: Die Eenheid van die Bybel', Die Hervormer 35(5), 4-5.

Van Zyl, F.J., 1944e, 'Skrifbeskouing van Karl Barth', HTS Theological Studies 1(3), 124 135. https://doi.org/10.4102/hts.v1i3.3320

Van Zyl, F.J., 1945, 'Die Boek van alle boeke: Ons Bybel: Die Bybel en die verkondiging', Die Hervormer 35(11), 6-7

Van Zyl, F.J., 1948, Die Boek van alle boeke: Ons Bybel, HAUM/De Bussy, Kaapstad.

Van Zyl, F.J., 1972, 'Die sendingtaak van die kerk: 'n Prinsipiële behandeling', HTS Teologiese Studies/Theological Studies 28(5), 173-182.

Van Zyl, F.J., 1973, 'Godsdienswetenskap en godsdiensfilosofie', in I. Eybers (red.), Inleiding in die teologie, pp. 143-156, NG Kerk Boekhandel, Pretoria.

Van Zyl, F.J., 1992, 'Die lewe en werk van HP Wolmarans, teologiese dosent 19351959', HTS Teologiese Studies/Theogical Studies 48(1\&2), 363-379.

Van Zyl, F.J., 1993, Die mens as sondaar: Karl Barth se beskouing, Kital, Pretoria.

Van Zyl, F.J., 1999, 'Aktualiteit en neerslag van Karl Barth se versoeningsleer in ons teologie', in D.J.C. van Wyk (red.), 20ste eeu Hervormde teologie, pp. 406-419, Sentik, Pretoria.

Woltersdorff, N., 1996, 'Die Mühsal der Theologie in der modernen Universität', in C. Krieg, T. Kucharz \& M. Volf (eds.), Die Theologie auf dem Weg in das dritte Jahrtausend: Festschrift für Jürgen Moltmann zum 70. Geburtstag, pp. 35-46, Gütersloher Verlagshaus, Gütersloh. 